This is an author produced version of a paper published in Bioenergy Research.

This paper has been peer-reviewed but may not include the final publisher proof-corrections or pagination.

Citation for the published paper:

Hammar, Torun; Ericsson, Niclas; Sundberg, Cecilia; Hansson, Per-Anders. (2014) Climate impact of willow grown for bioenergy in Sweden. Bioenergy Research. Volume: 7, Number: 4, pp 1529-1540. http://dx.doi.org/10.1007/s12155-014-9490-0.

Access to the published version may require journal subscription. Published with permission from: Springer Verlag.

Epsilon Open Archive http://epsilon.slu.se 


\title{
Climate impact of willow grown for bioenergy in Sweden
}

\author{
Torun Hammar, Niclas Ericsson, Cecilia Sundberg and Per-Anders Hansson \\ Department of Energy and Technology, Swedish University of Agricultural Sciences (SLU), Uppsala, SE-750 07, \\ Sweden \\ Correspondence: Torun Hammar, phone: +46(0)186718 30, fax: +46(0)18673156, \\ e-mail:torun.hammar@slu.se
}

\begin{abstract}
Short rotation coppice willow (SRCW) is a fast-growing and potentially high-yielding energy crop. Transition to bioenergy has been identified in Sweden as one strategy to mitigate climate change and decrease the current dependency on fossil fuel. In this study, life cycle assessment was used to evaluate and compare the climate impacts of SRCW systems, for the purpose to evaluate key factors influencing the climate change mitigation potential of SRCW grown on agricultural land in Sweden. Seven different scenarios were defined and analysed to identify the factors most influencing the climate. A carbon balance model was used to model carbon fluxes between soil, biomass and atmosphere under Swedish growing conditions. The results indicated that SRCW can act as a temporary carbon sink and therefore has a mitigating effect on climate change. The most important factor in obtaining a high climate change mitigating effect was shown to be high yield. Low yield gave the worst mitigating effect of the seven scenarios but it was still better than the effect of the reference systems, district heating produced from coal or natural gas.
\end{abstract}

Keywords: short rotation coppice willow (SRCW), life cycle assessment (LCA), soil organic carbon (SOC), greenhouse gas (GHG), Salix

\section{Introduction}

There is now consensus amongst most scientists that climate change is a human-induced problem that needs to be dealt with immediately, but the question is how. In December 2010, the United Nations Framework Convention on Climate Change (UNFCCC) formulated the Cancun Agreements, which stated that clear mitigation goals are needed to limit the global surface temperature rise to $2{ }^{\circ} \mathrm{C}$ [1]. In Europe, the European Union (EU) has agreed joint mitigation goals for all member states, referred to as the "20-20-20" targets, with the objective of reducing the level of greenhouse gases (GHGs), increasing the proportion of renewable energy and improving energy efficiency, all by $20 \%$ by 2020 compared with the base year 1990 [2]. To meet these targets, bioenergy has been identified as an alternative to fossil fuel for producing heat and electricity. One possible way to increase the proportion of bioenergy used and simultaneously reduce GHG emissions compared with fossil energy is to grow short rotation forestry on former arable soils, due to the potential this provides to store carbon in the soil $[3,4]$, decreasing the concentration of GHGs in the atmosphere.

In Sweden, the area used for energy forestry was around $0.5 \%$ of the total arable land in 2010 [5]. In the same year, about $6.7 \%$ of the arable land was under fallow [5], which indicates a potential to increase the proportion of energy forestry without claiming land currently used for food or feed production. About 12,000 hectares of land are currently cropped with short rotation coppice willow (SRCW), the most common type of energy forestry in Sweden [6]. SRCW is a fast-growing, high-yielding energy crop that can be burnt or gasified to produce heat and power [7]. It was introduced into Sweden during the early 1990s, with good prospects of high yield levels. However, the practical results did not live up to the high expectations due to inefficient management, unsuitable willow clones and use of low productivity land [8,9]. This, in combination with high transportation costs and low prices due to inefficient establishment strategies, resulted in poor profitability for willow farmers [6]. Since the 1990s, new clones that are better adapted to Swedish growing conditions have been developed and this, together with an increased demand for renewable energy sources, is likely to increase the interest in SRCW [6]. The 
production of willow biomass depends on climate conditions and soil quality, as well as management regime, fertilisation, pest control, rotation interval and planting density [10]. The soil type is important for achieving high productivity, and low clay content has been shown to reduce SRCW yield [9].

A common method for evaluating the climate impacts of energy crops is life cycle assessment (LCA) [11], a standardised method (ISO 14040, 14044) for evaluating potential effects and impacts of a product or service. The method considers all flows of energy and all emissions during the whole lifespan of the product or service, including the production and usage phase. LCAs of SRCW have been performed before [3,4,7,12-14], commonly by using the climate impact metric global warming potential (GWP), which expresses the integrated radiative forcing over a chosen period. However, the relationship between GWP and other metrics (e.g. temperature response) is complex and its use has been questioned. The results may be misinterpreted, with policymakers assuming that emissions with equal GWP have the same impact on the global temperature, although the relationship may be non-linear [15]. Impulse emissions of a strong GHG with a short lifetime and a weak GHG with a longer lifetime could have the same GWP, but still lead to different climate impacts [16]. To avoid some uncertainties associated with GWP and capture how the climate impact varies over time, an absolute climate metric can be used [17]. Climate metrics that consider the temporal variations in GHG emissions have been used previously in LCAs $[3,18,19]$.

Bioenergy can be considered carbon neutral in the sense that the carbon emitted from the combustion process will be recaptured once again in new plant tissue, but there is however a time difference between carbon uptake and carbon release. This is important to consider when assessing the climate impact, since for a certain period there will be a change in the GHG concentration in the atmosphere, affecting the climate. Another important factor to consider when performing LCAs of bioenergy systems is the change in soil organic carbon (SOC). Carbon can be captured in the soil by growing perennial crops, and therefore carbon fluxes between soil, biomass and atmosphere should be included in LCAs. A new method that considers temporal fluctuations and SOC changes was recently developed by Ericsson et al. [3]. Application of the method to an SRCW system to study the climate impacts revealed that such systems have the potential to sequester carbon and counteract global warming. However, that analysis was limited to one production system under two previous land use regimes. For a deeper understanding of the climate impact of willow grown in Sweden, more aspects of the land and management need to be included in LCAs. The potential of SRCW systems under different growing conditions also needs to be examined, in order to provide a better understanding of how marginal land can be used for bioenergy and identify the key elements determining the climate impact. The aims of this study were therefore to evaluate: (1) key factors influencing the climate change mitigation potential of SRCW grown on agricultural land in Sweden; (2) the potential to store soil organic carbon and create a carbon sink; and (3) the sensitivity of the models used to calculate carbon and climate effects.

\section{Method}

\subsection{Goal and scope}

The energy balance and climate impact from using agricultural land to produce SRCW under Swedish conditions were analysed using process-based LCA methodology $[20,21]$. The functional unit was set to one hectare of arable land and the impact categories were climate impact and energy use. Two methods were used to analyse climate impact; global warming potential $\left(\mathrm{GWP}_{100}\right)$ and the time-dependent climate impact methodology developed by Ericsson et al. [3], which accounts for the dynamic impacts related to timing of emissions and uptake of GHGs. The three major GHGs carbon dioxide $\left(\mathrm{CO}_{2}\right)$, methane $\left(\mathrm{CH}_{4}\right)$ and nitrous oxide $\left(\mathrm{N}_{2} \mathrm{O}\right)$ were used for calculating the GWP and temperature response. A carbon balance model referred to as the Introductory Carbon Balance Model (ICBM) was used for calculating carbon flows between soil, biomass and atmosphere [22]. Seven different scenarios were studied to assess the climate impact under various conditions. A sensitivity analysis was compiled to address the effects of model assumptions and data uncertainties. 


\subsubsection{System boundaries}

The SRCW system studied covered every process from the production of seedlings to the production of heat at a district heating $(\mathrm{DH})$ plant. This included flows of energy and emissions from field operations, production of inputs, transportation and the combustion process. Management practices and technologies used were assumed to be constant during the whole lifespan and no improvements were considered. Losses occurring downstream from the DH plant were not included within the system boundaries. Reference systems were defined to represent business-as-usual (BAU) scenarios. The reference systems consisted of an alternative land use and production of equivalent amounts of DH from fossil fuels [7,23].

\subsection{System description}

The hypothetical SRCW systems were based on recommendations for conventional willow cultivation in southeastern Sweden (Fig. 1). A 3-year or 4-year coppice cycle and a 25-year rotation period were assumed, meaning that harvesting took place every 3-4 years for 25 years. After one rotation period, the willow stool was assumed to be removed and new seedlings planted. The fossil reference systems included an alternative land use, which was the land management had there been no SRCW cultivation. The time frame for all scenarios was set to 100 years.

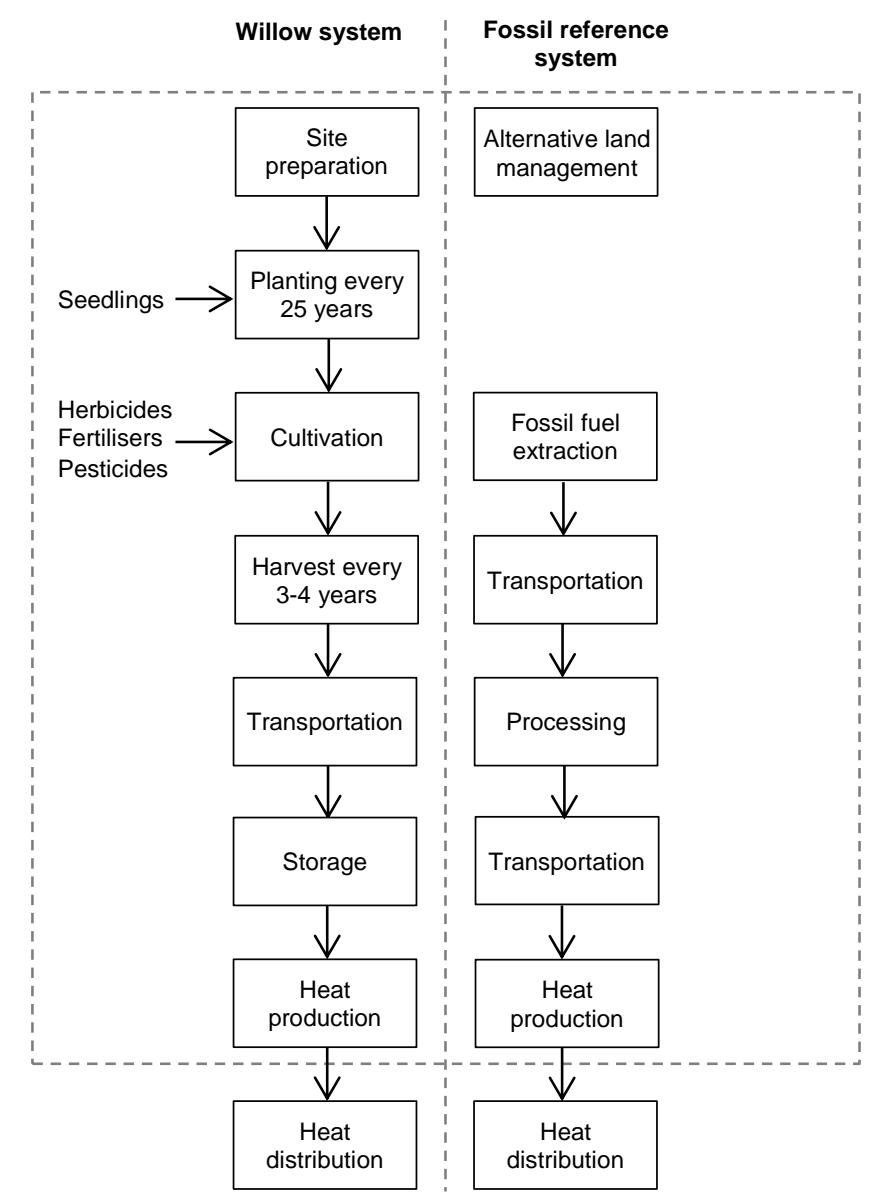

Fig. 1 Flowchart describing the SRCW systems and fossil reference systems for producing heat at a DH plant. Both include production of inputs, use of fossil fuel for machinery and transportation, and flows of GHG for each step. Dotted line indicates system boundaries

\subsubsection{Scenario descriptions}

Seven different scenarios of SRCW were studied (Table 1). The parameters varied were previous land use, willow yield, coppice cycle, time frame and succeeding land use. Two previous land use scenarios (nos. 2-3) were defined to analyse the impact of different initial SOC contents. One scenario (no. 4) was defined to analyse 
the impact on the SOC content of ending SRCW cultivation after one rotation period (25 years). Three scenarios (nos. 5-7) were defined to analyse the impact of different yield levels.

Table 1 Description of short rotation coppice willow (SRCW) scenarios 1-7 and the parameter values used in these scenarios. ( $\mathrm{LU}=$ land use)

\begin{tabular}{|c|c|c|c|c|c|c|c|}
\hline Scenario & 1 & 2 & 3 & 4 & 5 & 6 & 7 \\
\hline Description & Base scenario & $\begin{array}{l}\text { Previous } \\
\text { LU1 }\end{array}$ & $\begin{array}{l}\text { Previous } \\
\text { LU2 }\end{array}$ & $\begin{array}{l}\text { Ended } \\
\text { cultivation }\end{array}$ & $\begin{array}{l}\text { Improved } \\
\text { clone }\end{array}$ & $\begin{array}{l}\text { Low } \\
\text { yield }\end{array}$ & $\begin{array}{l}\text { High } \\
\text { yield }\end{array}$ \\
\hline $\begin{array}{l}\text { Previous land } \\
\text { use }\end{array}$ & Green fallow & Ley & $\begin{array}{l}\text { Annual } \\
\text { crops }\end{array}$ & Green fallow & Green fallow & $\begin{array}{l}\text { Green } \\
\text { fallow }\end{array}$ & $\begin{array}{l}\text { Green } \\
\text { fallow }\end{array}$ \\
\hline $\begin{array}{l}\text { Yield }\left(1^{\text {st}},\right. \\
\text { subsequent } \\
\text { harvest) } \\
\left(\text { odt ha }{ }^{-1}\right)\end{array}$ & $20,30^{\mathrm{a}}$ & $20,30^{\mathrm{a}}$ & $20,30^{\mathrm{a}}$ & $20,30^{\mathrm{a}}$ & $\begin{array}{l}20,30 \text { with } \\
10 \% \text { increase } \\
\text { every } 25^{\text {th }} y r .\end{array}$ & $10,17^{\mathrm{b}}$ & $\begin{array}{l}30^{\mathrm{c}} \\
42^{\mathrm{d}}\end{array}$ \\
\hline $\begin{array}{l}\text { Coppice cycle } \\
\text { (yr, no. of } \\
\text { cycles in } \\
\text { rotation) }\end{array}$ & 3,8 & 3,8 & 3,8 & 3,8 & 3,8 & 4,6 & 3,8 \\
\hline $\begin{array}{l}\text { Time frame } \\
\text { SRCW system } \\
(\mathrm{yr})\end{array}$ & 100 & 100 & 100 & 25 & 100 & 100 & 100 \\
\hline $\begin{array}{l}\text { Succeeding } \\
\text { land use }\end{array}$ & - & - & - & Green fallow & - & - & - \\
\hline $\begin{array}{l}\text { Fossil } \\
\text { reference } \\
\text { system }\end{array}$ & $\begin{array}{l}\text { (a) Coal, } \\
\text { (b) natural gas }\end{array}$ & Coal & Coal & Coal & Coal & Coal & Coal \\
\hline
\end{tabular}

\subsubsection{Yield}

The yield in the base scenario was assumed to be 20 oven dry tonnes (odt) ha ${ }^{-1}$ at the first harvest and 30 odt ha $^{-1}$ at subsequent harvests [6]. SRCW gives about 40\% higher yield in subsequent harvests due to the greater efficiency of the established root system [8]. One low-yield scenario (no. 6), one high-yield scenario (no. 7) and one improved clone scenario (no. 5) were also studied. In the low-yield scenario, a longer coppice cycle was assumed as a result of the low SRCW productivity. A new clone with $10 \%$ higher yield was assumed in each rotation period in the improved clone scenario. The distribution of stem growth for the 3-year coppice cycles during both the first and subsequent cycles were assumed to be 25\%, 40\% and 35\% for years 1, 2 and 3 [3]. An equal stem growth distribution of $25 \%$ per year was assumed for the 4-year coppice. By using the distribution of annual net primary production (NPP) [26], the quantity of leaves, fine roots and coarse roots was calculated (Table 2).

Table 2 Annual net primary production (NPP) for the first and subsequent coppice cycles (\% of annual stem growth), based on Rytter [26]

\begin{tabular}{lllllllllllll}
\hline & Leaves & \multicolumn{4}{c}{} & \multicolumn{4}{c}{ Fine roots } & \multicolumn{5}{c}{ Coarse roots } \\
\hline Year & 1 & 2 & 3 & 4 & 1 & 2 & 3 & 4 & 1 & 2 & 3 & 4 \\
\hline $1^{\text {st }}$ cycle & 25 & 30 & 27 & 27 & 60 & 71 & 70 & 70 & 39 & 19 & 12 & 12 \\
$2^{\text {nd }}-8^{\text {th }}$ cycle & 31 & 31 & 31 & 31 & 69 & 69 & 69 & 69 & 0 & 0 & 0 & 0 \\
\hline
\end{tabular}

\subsubsection{Mineral fertiliser}

Mineral fertiliser can cause both direct and indirect emissions of $\mathrm{N}_{2} \mathrm{O}$ through nitrification and denitrification. Negatively charged nitrate ions that are created through nitrification can be leached by drainage water [27]. In the present study, the amount of mineral fertiliser applied was based on yield and losses, so that the amounts of 
nutrients leaving the system equalled the amounts added to maintain an unchanged mass balance. The nitrogen content in stems was assumed to be $0.43 \%$ [3]. The direct and indirect emissions from the fertilisers applied $\left(N_{\text {applied }}\right)$ were calculated by:

$$
\begin{aligned}
& \mathrm{N}_{2} \mathrm{O}_{\text {direct }}=E F_{N} \cdot\left(N_{\text {applied }}+N_{\text {litter }}+N_{\text {fine roots }}\right) \cdot \frac{44}{28} \\
& \mathrm{~N}_{2} \mathrm{O}_{\text {indirect }}=N_{\text {applied }} \cdot\left(F_{A} \cdot E F_{D}+N_{\text {leached }} \cdot E F_{L}\right) \cdot \frac{44}{28}
\end{aligned}
$$

where $N_{\text {leached }}$ is the nitrogen lost by leaching, and $N_{\text {litter }}$ and $N_{\text {fine roots }}$ are the amount of nitrogen contained in aboveground litter and fine roots. Default values were used as emission factors due to lack of specific data (Table 3). The fraction $\frac{44}{28}$ converts $\mathrm{N}$ into $\mathrm{N}_{2} \mathrm{O}[28]$.

\begin{tabular}{|c|c|c|c|}
\hline Parameter & Description & Value & Unit \\
\hline$N_{\text {leached }}$ & $\mathrm{N}$ lost by leaching & $0.30^{\mathrm{c}}$ & $\mathrm{kg} \mathrm{N} \mathrm{kg}^{-1}$ applied $\mathrm{N}$ \\
\hline$N_{\text {fine roots }}$ & $\mathrm{N}$ content in fine roots & $0.43^{\mathrm{a}}$ & $\%$ \\
\hline$N_{\text {litter }}$ & $\mathrm{N}$ content in litter & $2.5^{\mathrm{a}}$ & $\%$ \\
\hline$E F_{N}$ & Direct emissions from applied $\mathrm{N}$ & $0.01^{\mathrm{b}, \mathrm{c}}$ & $\mathrm{kg} \mathrm{N}_{2} \mathrm{O}-\mathrm{N} \mathrm{kg}^{-1} \mathrm{~N}$ \\
\hline$E F_{L}$ & $\mathrm{~N}_{2} \mathrm{O}$ emissions due to $\mathrm{N}$ leaching & $0.0075^{\mathrm{b}, \mathrm{c}}$ & $\mathrm{kg} \mathrm{N}_{2} \mathrm{O}-\mathrm{N} \mathrm{kg}^{-1}$ leached $\mathrm{N}$ \\
\hline$E F_{D}$ & $\begin{array}{l}\text { Emissions from volatilisation and re- } \\
\text { deposition }\end{array}$ & $0.01^{\mathrm{b}, \mathrm{c}}$ & $\mathrm{kg} \mathrm{N}_{2} \mathrm{O}-\mathrm{N} \mathrm{kg}^{-1} \mathrm{NH}_{3}-\mathrm{N}$ \\
\hline$F_{A}$ & $\begin{array}{l}\text { Fraction of applied } \mathrm{N} \text { emitted as } \\
\text { ammonia }\end{array}$ & $0.012^{\mathrm{b}}$ & $\begin{array}{l}\mathrm{kg} \mathrm{NH}_{3}-\mathrm{N}+\mathrm{NO}_{\mathrm{x}}-\mathrm{N} \mathrm{kg}^{-1} \text { applied } \\
\mathrm{N}\end{array}$ \\
\hline
\end{tabular}

Table 3 Parameters used for calculating $\mathrm{N}_{2} \mathrm{O}$ emissions by equation (1) and (2)

${ }^{\mathrm{a}}[3],{ }^{\mathrm{b}}[29],{ }^{\mathrm{c}}[28]$.

The recommendation that fertilisers should not be spread during the first coppicing cycle but during subsequent cycles was followed [30,31]. The assumed amounts of phosphorus (P) and potassium (K) applied were based on values from Börjesson [12].

\subsubsection{Harvest and combustion}

SRCW is usually harvested during the winter when the plant is dormant, the water content is low and the frozen soil has a high carrying capacity for machinery [32]. The willow was assumed to be harvested by direct chipping, after which it was stored in containers and thereafter transported to the DH plant located $30 \mathrm{~km}$ from the site. The willow chips were assumed to be stored at an average daytime temperature of maximum $5{ }^{\circ} \mathrm{C}$ and combusted within 30 days, leading to a dry matter loss of 3\% [33]. The efficiency rate of the DH plant was assumed to be $85 \%$ and a high heating value was used. $\mathrm{CO}_{2}$ emissions due to the combustion were calculated

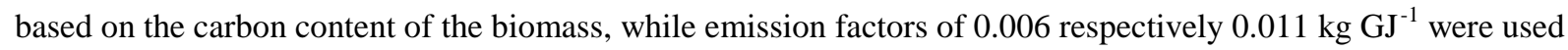
for calculating $\mathrm{N}_{2} \mathrm{O}$ and $\mathrm{CH}_{4}$ emissions [34].

\subsubsection{Land use}

In order to determine the SOC sequestering potential of willow cultivation, initial soil conditions were calculated by defining a previous land use for each scenario. For the base scenario, the previous land use was set to a 20year old green fallow that had formerly been used to grow annual crops. Green fallow was defined as land set aside and topped annually to prevent tree growth. The green biomass was assumed to be left in the field to decompose, which gave a carbon input to the soil. Two additional land uses were also considered; annual crops (LU1) and ley (LU2) (scenarios 2 and 3). Ley was defined as unfertilised land harvested for hay or green fodder. Annual crops were modelled using data for spring and winter cereals. 


\subsubsection{Fossil reference system}

Two types of fossil reference systems were analysed in this study; heat production from coal at a DH plant and heat production from natural gas (Table 4).

Table 4 Emission factors for district heating from coal and natural gas $\left(\mathrm{kg} \mathrm{GJ}^{-1}\right)$

\begin{tabular}{|c|c|c|c|}
\hline Reference system & $\mathrm{CO}_{2}$ & $\mathrm{CH}_{4}$ & $\mathrm{~N}_{2} \mathrm{O}$ \\
\hline (a) $\mathrm{Coal}^{\mathrm{a}}$ & 94.2 & 1.1005 & 0.012 \\
\hline (b) Natural gas & 59.1 & 0.0075 & 0.00105 \\
\hline
\end{tabular}

${ }^{a}$ Production, distribution and usage at heating plant [35].

The fossil reference system was assumed to produce the same amount of heat in the same year as the SRCW system. Green fallow was assumed as the alternative land use in the reference systems. Use of fossil fuel for topping the land once every year was included in the LCA.

\subsection{Soil organic carbon}

ICBMr is a soil carbon balance model adapted for variable annual input due to regional differences. The model calculates carbon fluxes due to changes in soil organic carbon (SOC). ICBM has two assumed soil carbon pools, one young $(Y)$ and one old $(O)$, the relationship between which is calculated by:

$Y_{[a, b]}(t)=\left(Y_{[a, b]_{t-1}}+i_{[a, b]_{t-1}}\right) \cdot \exp ^{-k_{Y} \cdot r_{e}}$

$O(t)=\left(O_{t-1}-\left(\frac{h_{a} \cdot k_{Y}}{\left(k_{O}-k_{Y}\right)} \cdot\left(Y_{a_{t-1}}+i_{a_{t-1}}\right)+\frac{h_{b} \cdot k_{Y}}{\left(k_{O}-k_{Y}\right)} \cdot\left(Y_{b_{t-1}}+i_{b_{t-1}}\right)\right)\right) \cdot \exp ^{-k_{O} \cdot r_{e}}+$

$\left(\frac{h_{a} \cdot k_{Y}}{\left(k_{O}-k_{Y}\right)} \cdot\left(Y_{a_{t-1}}+i_{a_{t-1}}\right)+\frac{h_{b} \cdot k_{Y}}{\left(k_{O}-k_{Y}\right)} \cdot\left(Y_{b_{t-1}}+i_{b_{t-1}}\right)\right) \cdot \exp ^{-k_{y} \cdot r_{e}}$

where $k_{Y}$ and $k_{O}$ are constants. External factors (e.g. weather, soil type) affecting the decomposition rate are described by $r_{e}$ [22]. The humification coefficient $h$ describes the magnitude of the fraction of the young pool that enters the old pool. The suffixes $a$ and $b$ represent aboveground biomass (leaves) and belowground biomass (roots, stumps), respectively. The relationship between the aboveground and belowground humification coefficients is described by:

$h_{b}=2.3 \cdot h_{a}$

[22], and the annual aboveground carbon input to the soil $i_{a}$ (Table 5) is calculated by:

$i_{a}=A+s \cdot H$

where $A$ and $s$ are empirically based parameters that differ between straw, stubble, roots and different crops. $H$ is the carbon content of the biomass [22], in this study set to $50 \%$ for all parts of the biomass. The belowground input $i_{b}$ (Table 5) from fine root turnover and accumulated coarse roots and stumps can be described by:

$i_{b}=\frac{H \cdot R_{m} \cdot R_{R E}}{1-R_{R E} / 0.85}$

where $R_{m}$ is the root mass fraction and $R_{R E}$ is the relative carbon fraction allocated to roots, including rhizodeposition [22]. The total SOC content in the topsoil $(0-25 \mathrm{~cm})$ is calculated by adding the pools:

$\operatorname{SOC}(t)=Y_{a}(t)+Y_{b}(t)+O(t)$

Here, $k_{Y}$ and $k_{O}$ (0.8 and 0.0085 [3]) were calibrated using values from the Ultuna long-term soil experiment [36]. $r_{e}$ was set to 1.0 , which represents the annual mean conditions for fertilised cereal crops grown on clay soil in Ultuna, Sweden [37]. 
Table 5 Annual carbon input to the soil due to different land uses $\left(\mathrm{Mg} \mathrm{C} \mathrm{yr}^{-1}\right.$ and $\left.\mathrm{ha}^{-1}\right)$, calculated using equations (6) and (7)

\begin{tabular}{|c|c|c|}
\hline & Aboveground $\left(i_{a}\right)$ & Belowground $\left(i_{b}\right)$ \\
\hline Green fallow $^{\mathrm{a}}$ & 0.7 & 1.4 \\
\hline Annual crops ${ }^{\mathrm{a}}$ & 3.3 & 0.7 \\
\hline Ley $^{b}$ & 1.1 & 1.5 \\
\hline \multicolumn{3}{|l|}{ Willow $^{\mathrm{c}}$} \\
\hline $1^{\text {st }}$ cycle $($ yrs. $1-3)$ & $0.6,1.2,0.9$ & $1.5,2.8,2.5$ \\
\hline $2^{\text {nd }}-8^{\text {th }}$ cycle (yrs. $\left.4-24\right)$ & $1.2,1.9,1.6$ & $2.6,4.1,3.6$ \\
\hline
\end{tabular}

The SOC content was converted into proportion $\left(\mathrm{g} \mathrm{C} \mathrm{g}^{-1}\right)$ of the topsoil $(0-25 \mathrm{~cm})$ by:

$S O C=\frac{\rho_{\text {bulk }}}{\rho_{\text {particle }}}$

where $\rho_{\text {bulk }}$ is the SOC bulk density measured in $\mathrm{g} \mathrm{C} \mathrm{cm}^{-3}$ and $\rho_{\text {particle }}$ is the soil particle density measured in $\mathrm{g}$ $\mathrm{cm}^{-3}$. The particle density was assumed to be $2.65 \mathrm{~g} \mathrm{~cm}^{-3}$ [39] and $\rho_{\text {bulk }}$ was calculated by dividing the SOC mass $\left(\mathrm{Mg} \mathrm{C} \mathrm{ha}^{-1}\right)$ by the soil volume $(1$ ha $\mathrm{x} 25 \mathrm{~cm})$. The belowground annual carbon input $\left(i_{b}\right)$ was recalculated by setting $R_{m}$ to 0.7 to only account for the topsoil and not the entire soil profile [39].

\subsection{Energy indicators}

Two different energy indicators were used to quantify the energy performance. The first one, referred to as the life cycle efficiency (LCE), was defined as net energy output divided by biomass energy:

$L C E=\frac{E_{\text {out }}-E_{\text {in }}}{E_{\text {bio }}}$

where $E_{\text {out }}$ is the energy produced at the DH plant, $E_{\text {in }}$ the total energy input in the upstream processes, and $E_{\text {bio }}$ the energy contained in the willow biomass. LCE is an indicator of the overall efficiency of the SRCW system [7]. The second energy indicator used was the energy ratio (ER), which is the ratio between the energy produced at the DH plant and the total energy input:

$E R=\frac{E_{\text {out }}}{E_{\text {in }}}$

ER is a commonly used energy efficiency indicator that describes the overall energy output per unit energy input [7]. Contrary to LCE, it does not explicitly consider the efficiency of biomass utilisation. There is no standardised method for calculating ER and the concept can be referred to in other ways, e.g. Energy Return On Energy Investment (EROI) [40].

\subsection{Climate impact}

Global warming potential $\left(\mathrm{GWP}_{100}\right)$ and global mean surface temperature change were used as climate impact indicators. $\mathrm{GWP}_{100}$ indicates the cumulative radiative effect of a given substance relative to another, over a 100 year time horizon [41]. $\mathrm{CH}_{4}$ and $\mathrm{N}_{2} \mathrm{O}$ are stronger GHGs than $\mathrm{CO}_{2}$, with, respectively, a 25-fold and 298-fold stronger $\mathrm{GWP}_{100}$ [42]. Multiplying the net emissions of $\mathrm{CH}_{4}$ and $\mathrm{N}_{2} \mathrm{O}$ by their specific $\mathrm{GWP}_{100}$ characterisation factor converts the emissions into carbon dioxide equivalents $\left(\mathrm{CO}_{2}\right.$-eq). The $\mathrm{CO}_{2}$-eqs for all three GHGs were summed up to calculate the total $\mathrm{GWP}_{100}$. GWP does not consider the timing of the emissions. Therefore the time-dependent LCA method developed by Ericsson et al. [3] was used for calculating the temporal global mean surface temperature change, referred to as $\Delta T_{s}$. When GHGs are released, the atmospheric concentration is altered, which disturbs the energy balance on Earth. To model this process, an impulse response function (IRF) can be used (e.g. Bern CC model [43]). The change in concentration leads to a change in radiative forcing (RF), which describes the perturbation of the energy balance of Earth in $\mathrm{Wm}^{-2}$ [44]. RF can be either positive or negative, leading to either warming or cooling $\Delta T_{s}$. For a detailed explanation, see Ericsson et al. [3]. Indirect effects of $\mathrm{CH}_{4}$ were included by adding the fraction of gas oxidised into $\mathrm{CO}_{2}$ during the preceding year. 


\subsection{Sensitivity analysis}

According to Huijbregts [45], there are six different types of uncertainty and variability associated with the general framework of LCA: (1) parameter uncertainty; (2) model uncertainty; (3) uncertainty due to choices; (4) spatial variability; (5) temporal variability; and (6) variability between objects and sources. Even if data are collected carefully and standardised methods are followed, uncertainties cannot be avoided completely. By performing a sensitivity analysis, it is possible to determine the degree of uncertainty different factors impose on the final results [46]. Sensitivity is the influence that one independent input parameter has on one other dependent parameter, and consequently on the final results [47].

As the scenario analysis in the present study captured variability and uncertainty due to choices, the sensitivity analysis focused on parameter and model uncertainty. In the sensitivity analysis, one input parameter was varied at a time while all other parameters were kept constant. The purpose was to see how much the selected parameter affected the results. To address the uncertainties related to SOC modelling, the external factor $\left(r_{e}\right)$ and the humification parameter $(h)$ in the ICBM model were analysed. The net primary production (NPP) for leaves and fine roots influences the SOC and for that reason it was also analysed. Default values for nitrogen leakage $\left(N_{\text {leached }}\right)$ and emissions due to applied fertilisers $\left(E F_{N}\right)$ are also uncertain and were therefore evaluated in the sensitivity analysis. All six parameters were varied one at a time by $\pm 20 \%$ relative to the base scenario.

\section{Results and discussion}

\subsection{Greenhouse gases and soil organic carbon}

The inventory analysis showed that the base scenario had the potential to capture $50 \mathrm{Mg} \mathrm{C}^{-1}$ in the soil during four rotation periods (100 years), leading to a total SOC content of $1.7 \%$ in the topsoil (Table 6). The high yield scenario (no. 7) showed the greatest potential to sequester carbon, capturing $92 \mathrm{Mg} \mathrm{C}^{-1}$. The low yield scenario (no. 6), on the other hand, gave a reduced SOC level and emitted $12 \mathrm{MgC} \mathrm{ha}^{-1}$. This indicates that with a very low yield, a SRCW plantation will not work as a carbon sink. Among the previous land uses, green fallow was shown to give the lowest initial SOC level, followed by ley (LU1) and annual crops (LU2), but the differences in SOC due to previous land use were small. The scenario where the cultivation ended after one rotation period (no. 4) showed a larger sequestering potential than the low yield scenario (no. 6), which was a result of lower annual carbon input from aboveground and belowground willow biomass in the low yield scenario compared with the green fallow biomass in the ended cultivation scenario.

Table 6 Initial, total and net soil organic carbon (SOC) after 100 years. Total SOC (\% C) was calculated for the topsoil $(0-25 \mathrm{~cm})$, while the other figures represent the entire soil profile

\begin{tabular}{lllll}
\hline Scenario & $\begin{array}{l}\text { Initial SOC } \\
(\mathrm{yr} .0)\end{array}$ & $\begin{array}{l}\text { Total SOC } \\
(\mathrm{yr} .100)\end{array}$ & $\begin{array}{l}\text { Net SOC uptake } \\
\text { (yrs. 0-100) }\end{array}$ & $\begin{array}{l}\text { Total SOC in topsoil } \\
(\mathrm{yr} . \text { 100) }\end{array}$ \\
\hline & $\mathrm{Mg} \mathrm{C} \mathrm{ha}^{-1}$ & $\mathrm{Mg} \mathrm{C} \mathrm{ha}^{-1}$ & $\mathrm{Mg} \mathrm{Cha}^{-1}$ & $\% \mathrm{C}$ \\
\hline 1. Base scenario & 96 & 146 & 50 & 1.7 \\
2. Previous LU1 & 98 & 147 & 48 & 1.8 \\
3. Previous LU2 & 100 & 147 & 47 & 1.8 \\
4. Ended cultivation & 96 & 98 & 2 & 1.2 \\
5. Improved clone & 96 & 166 & 70 & 2.0 \\
6. Low yield & 96 & 84 & -12 & 1.0 \\
7. High yield & 96 & 188 & 92 & 2.2 \\
\hline
\end{tabular}

The high yield scenario gave the largest emissions of all three GHGs (Table 7). The inventory analysis showed that a high yield (scenario nos. 5 and 7) gave higher $\mathrm{N}_{2} \mathrm{O}$ emissions due to an increased fertilisation rate. The low yield scenario gave the lowest emission of all GHGs. 
Table 7 Net greenhouse gas emissions from willow cultivation and heat produced at a district heating (DH) plant (years 0-100). In unit $\mathrm{Mg} \mathrm{ha}^{-1}$

\begin{tabular}{llll}
\hline Scenario & $\mathrm{CO}_{2}$ & $\mathrm{~N}_{2} \mathrm{O}$ & $\mathrm{CH}_{4}$ \\
\hline 1. Base scenario & 45 & 0.38 & 0.23 \\
2. Previous LU1 & 45 & 0.38 & 0.23 \\
3. Previous LU2 & 45 & 0.38 & 0.23 \\
4. Ended cultivation & $\mathrm{a}$ & 0.10 & 0.06 \\
5. Improved clone & 11 & 0.44 & 0.27 \\
6. Low yield & 50 & 0.16 & 0.10 \\
7. High yield & 24 & 0.54 & 0.33 \\
\hline
\end{tabular}

${ }^{\mathrm{a}}$ First rotation period only.

\subsection{Energy use and efficiency}

The life cycle inventory showed that the base scenario gave an average annual energy output of $150 \mathrm{GJ} \mathrm{ha}^{-1} \mathrm{yr}^{-1}$. The high yield scenario gave the highest annual energy output (210 GJ ha- $\mathrm{yr}^{-1}$ ), followed by the improved clone scenario (170 GJ ha ${ }^{-1} \mathrm{yr}^{-1}$ ) (Table 8). The high yield scenario also gave the highest energy ratio (ER), 27.1 MJ DH produced per MJ input energy in the production chain. The life cycle efficiency (LCE) was 0.79 for all scenarios except the low yield scenario, which resulted in a slightly lower LCE of 0.78 . The increased use of fossil fuel for machinery and production of fertilisers in the high yield scenario contributed to the almost unchanged energy ratio.

Table 8 Energy use and efficiency for short rotation coppice willow (SRCW) systems during four rotation periods (years 0-100)

\begin{tabular}{|c|c|c|c|c|}
\hline Scenario & $\begin{array}{l}\text { Annual average energy } \\
\text { input }\left(\mathrm{GJ} \mathrm{ha}^{-1} \mathrm{yr}^{-1}\right)\end{array}$ & $\begin{array}{l}\text { Annual average energy } \\
\text { output }\left(\mathrm{GJ} \mathrm{ha}^{-1} \mathrm{yr}^{-1}\right)\end{array}$ & $\begin{array}{l}\text { Life cycle } \\
\text { efficiency } \\
\text { (LCE) }\end{array}$ & $\begin{array}{l}\text { Energy ratio } \\
\text { (ER) }\end{array}$ \\
\hline 1. Base scenario & 5.9 & 150 & 0.79 & 25.5 \\
\hline 2. Previous LU1 & 5.9 & 150 & 0.79 & 25.5 \\
\hline 3. Previous LU2 & 5.9 & 150 & 0.79 & 25.5 \\
\hline 4. Ended cultivation ${ }^{\mathrm{a}}$ & 5.8 & 150 & 0.79 & 25.2 \\
\hline 5. Improved clone & 6.6 & 170 & 0.79 & 26.3 \\
\hline 6. Low yield & 3.0 & 61 & 0.78 & 20.4 \\
\hline 7. High yield & 7.8 & 210 & 0.79 & 27.1 \\
\hline
\end{tabular}

${ }^{\mathrm{a}}$ First rotation period only.

\subsection{Global warming potential}

The life cycle impact assessment showed that the base scenario gave a total $\mathrm{GWP}_{100}$ of $-16 \mathrm{Mg} \mathrm{CO}_{2}$-eq ha ${ }^{-1}$, not including the effect of substituting fossil fuel. The lowest $\mathrm{GWP}_{100}$ was obtained with the high yield scenario ($110 \mathrm{Mg} \mathrm{CO}_{2}$-eq ha $\left.{ }^{-1}\right)$, whereas the low yield scenario gave the highest global warming potential $\left(108 \mathrm{Mg} \mathrm{CO}_{2}\right.$-eq $\mathrm{ha}^{-1}$ ) (Table 9). This further indicates the importance of high yield for achieving a climate change mitigating effect. If coal were to be replaced by the SRCW system, a mitigating effect of -564 to $-3340 \mathrm{Mg} \mathrm{CO}_{2}-\mathrm{eq} \mathrm{ha}^{-1}$ could be obtained. The impact assessment also showed that natural gas (scenario 1b) released $1090 \mathrm{Mg} \mathrm{CO}_{2}$-eq per MJ DH produced during the entire time frame (100 years), whereas the coal system emitted over double that amount, $2300 \mathrm{Mg} \mathrm{CO}_{2}$-eq per $\mathrm{MJ} \mathrm{DH}$ produced. 
Table 9 Global warming potential $\left(\mathrm{GWP}_{100}\right)$ for the short rotation coppice willow (SRCW) systems and fossil reference systems, and potential reduction if SRCW systems replaced the reference systems. Units are $\mathrm{Mg} \mathrm{CO}_{2}-$ eq ha ${ }^{-1}$ and $\mathrm{g} \mathrm{CO}_{2}$-eq $\mathrm{MJ}^{-1}$ district heating $(\mathrm{DH})$ for years 0-100. A positive value indicates emission to the atmosphere, a negative value reduction

\begin{tabular}{|c|c|c|c|c|c|c|c|}
\hline \multirow[t]{2}{*}{ Scenario } & \multicolumn{2}{|c|}{ SRCW system } & \multicolumn{2}{|c|}{ Fossil reference system } & \multicolumn{3}{|c|}{ Reduction } \\
\hline & $\mathrm{Mg} \mathrm{ha}^{-1}$ & $\mathrm{~g} \mathrm{MJ}^{-1}$ & $\mathrm{Mg} \mathrm{ha}^{-1}$ & $\mathrm{~g} \mathrm{MJ}^{-1}$ & $\mathrm{Mg} \mathrm{ha}^{-1}$ & $\mathrm{~g} \mathrm{MJ}^{-1}$ & $\%$ \\
\hline \multicolumn{8}{|l|}{ 1. Base scenario } \\
\hline (a) Coal & -16 & -1.1 & 2300 & 152 & -2320 & -154 & -101 \\
\hline (b) Natural gas & -16 & -1.1 & 1090 & 72 & -1100 & -73 & -101 \\
\hline 2. Previous LU1 & -11 & -0.8 & 2280 & 151 & -2290 & -152 & -100 \\
\hline 3. Previous LU2 & -6 & -0.4 & 2270 & 150 & -2280 & -151 & -100 \\
\hline 4. Ended cultivation ${ }^{a}$ & 1740 & 115 & 2300 & 152 & -564 & -37 & -25 \\
\hline 5. Improved clone & -69 & -3.9 & 2660 & 152 & -2730 & -156 & -103 \\
\hline 6. Low yield & 108 & 17 & 960 & 155 & -854 & -140 & -89 \\
\hline 7. High yield & -110 & -5.2 & 3230 & 152 & -3340 & -160 & -103 \\
\hline
\end{tabular}

${ }^{\mathrm{a}} \mathrm{SRCW}$ for first rotation period, followed by DH from coal.

\subsection{Temperature response}

The base scenario gave a negative temperature response, i.e. contributed to lowering of the global mean temperature (Fig. 2). The temperature response $\left(\Delta T_{s}\right)$ stabilised around $-0.35 \cdot 10^{-10} \mathrm{~K} \mathrm{ha}^{-1}$, with small oscillations as a result of harvest taking place every 3-4 years and larger oscillations due to the removal of willow stool every 25 years. The low yield scenario showed a positive temperature response that contributed to raising the global mean temperature. The high yield scenario, on the other hand, had the highest cooling effect of all scenarios. The previous land use scenarios had similar, but slightly smaller, cooling effects than the base scenario.

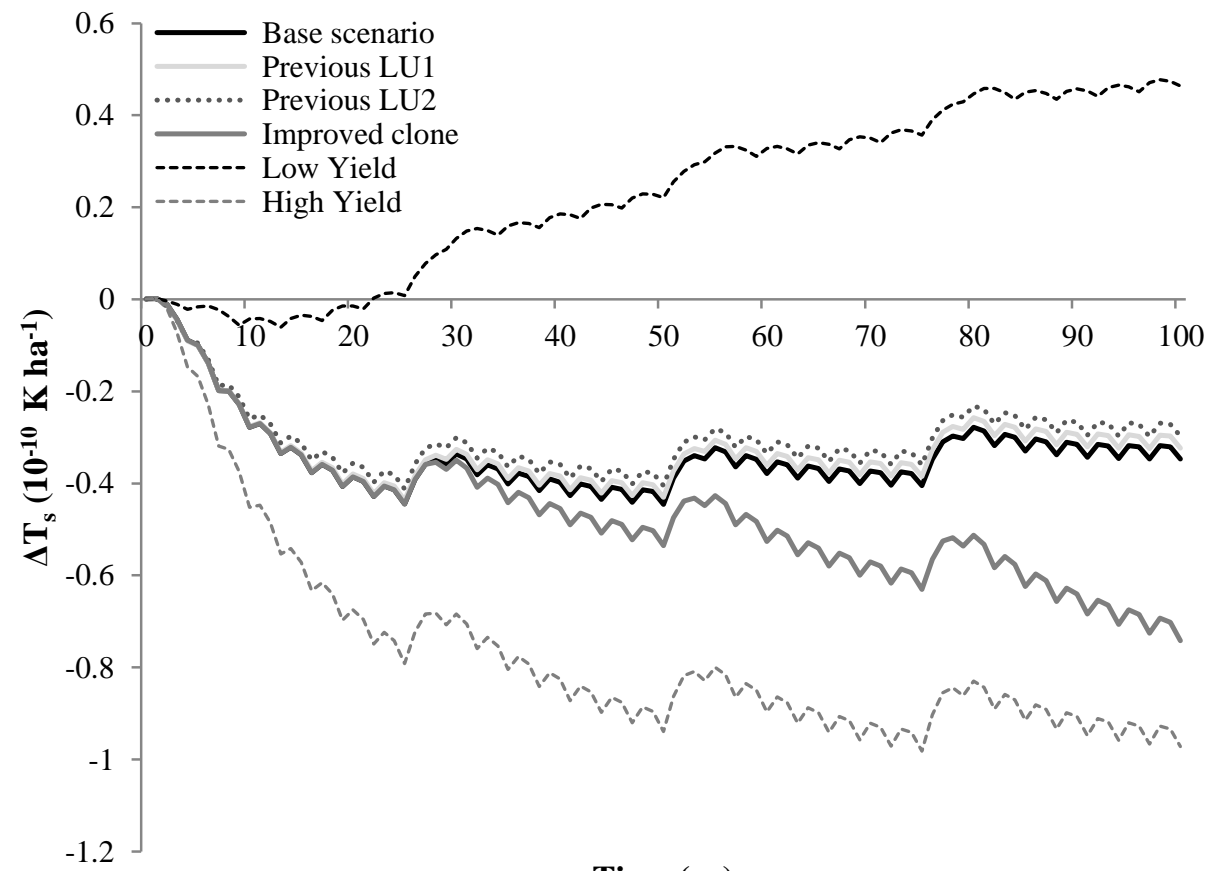

Time (yr)

Fig. 2 Time-dependent temperature response $\left(\Delta T_{s}\right)$ for scenarios 1-3 and 5-6, with the fossil reference scenarios not included. The low yield scenario had a warming effect on the temperature, while all other scenarios had a cooling effect 
If the SRCW cultivation were to end after one rotation period (scenario 4) and instead be replaced by green fallow, the succeeding land use would bind less carbon to the soil due to loss of living biomass and annual carbon input to the soil (Fig. 3). This indicates that the cooling effect is only short-term and that ending SRCW cultivation would lower the SOC level. The succeeding land use for the ended cultivation scenario showed a small sequestering effect (Table 6), but not enough to counteract the combustion of coal to produce DH.

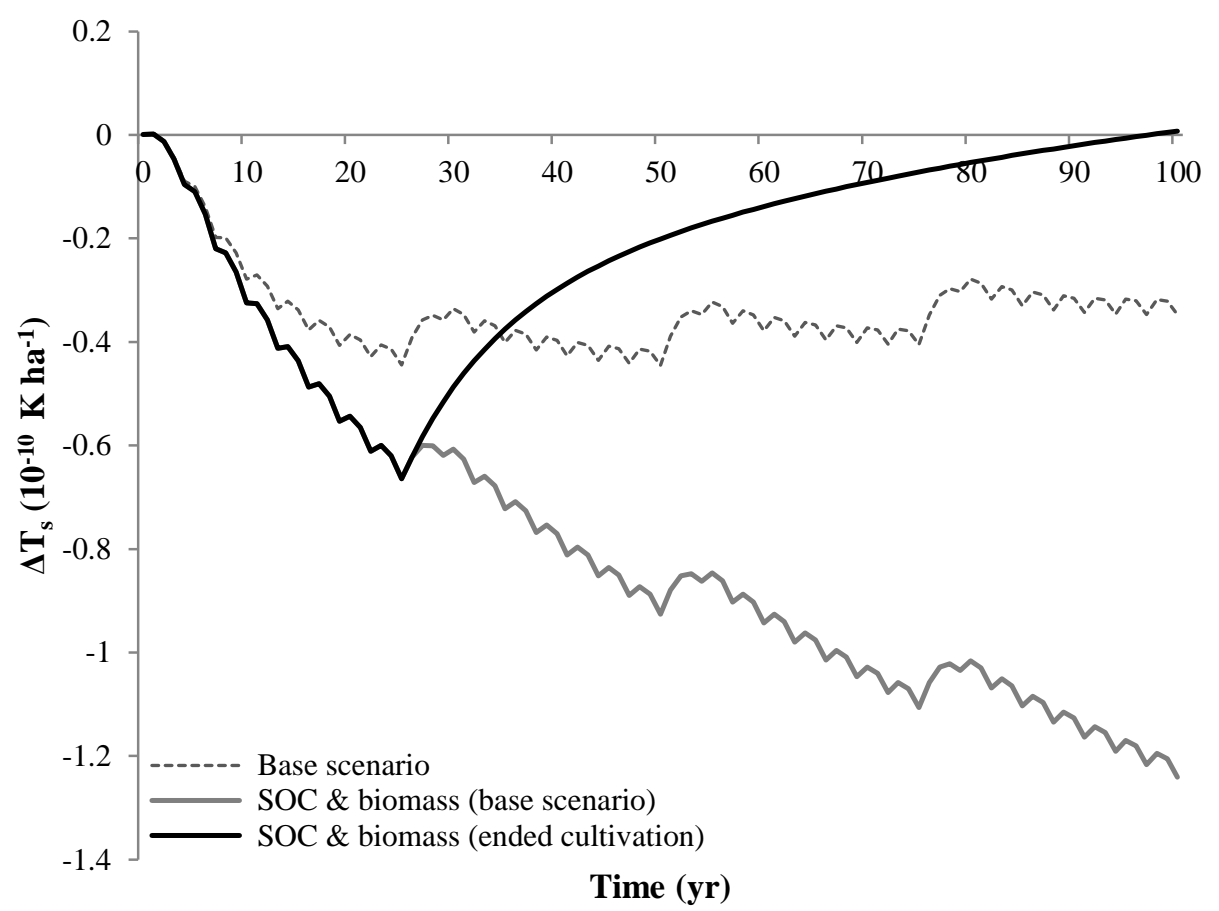

Fig. 3 Time-dependent global mean surface temperature change $\left(\Delta T_{s}\right)$ due to carbon fluxes between soil, biomass and atmosphere. Emissions from management operations, transportation and production of DH are not included

Compared with the reference systems (coal and natural gas), all SRCW scenarios had a mitigating climate effect. The coal reference system (scenario 1a) gave a higher temperature rise than the natural gas system (scenario 1b) (Fig. 4). The low SRCW yield scenario gave a cooling temperature response when the substitution effect was included, even if the SRCW system showed a small warming effect. 


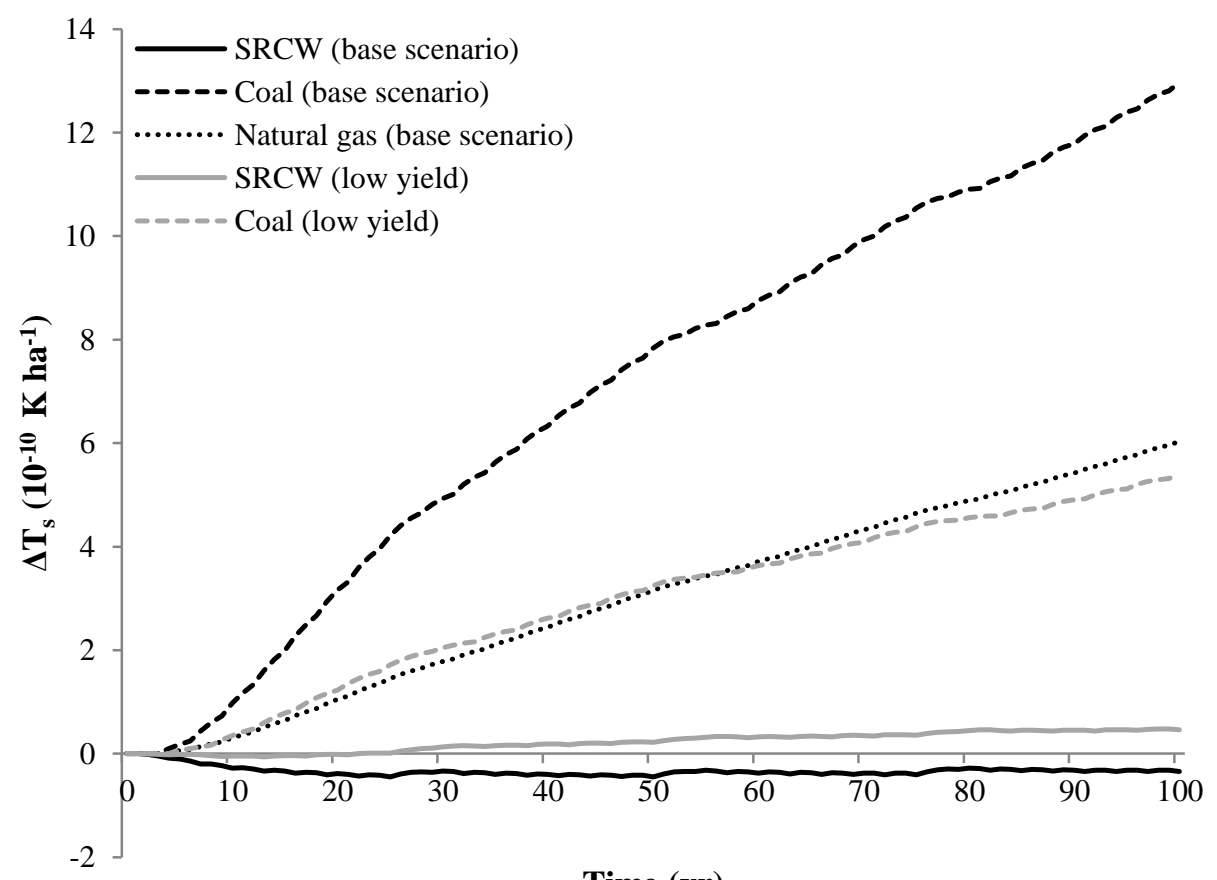

Time (yr)

Fig. 4 Time-dependent global mean surface temperature change $\left(\Delta T_{S}\right)$ for the base scenario (no. 1; black lines) and the low-yield scenario (no. 6; grey lines)

\subsection{Sensitivity analysis}

The sensitivity analysis showed that of the parameters analysed, the NPP for fine roots, $r_{e}$ and $h$ in the soil C model had the largest impact on the temperature response $\Delta T_{s}$ (Table 10). High $h$ or high NPP for fine roots gave a larger cooling effect, as did low $r_{e}$. High $r_{e}$ means that $\mathrm{C}$ input to the soil will be decomposed faster, increasing the $\mathrm{CO}_{2}$ concentration in the atmosphere and thus the temperature response. Increased NPP of fine roots also affects the amount of carbon stored in the soil. The amount of leached nitrogen $\left(N_{\text {leached }}\right)$, NPP for leaves and direct emissions from nitrogen fertilisers $\left(E F_{N}\right)$ gave a smaller impact on the results. However, even though these parameters contained large uncertainties, they contributed only a small amount to the overall sensitivity of the results.

Table 10 Sensitivity analysis of final temperature response $\left(\Delta T_{S}\right)$ at year 100 when different parameters were varied by $\pm 20 \%$. In unit $10^{-10} \mathrm{~K} \mathrm{ha}^{-1}$ and relative change to the base scenario $\left(-0.35 \cdot 10^{-10} \mathrm{~K} \mathrm{ha}^{-1}\right)(\%)$, where a positive change indicate a larger cooling effect

\begin{tabular}{lllllll}
\hline & $r_{e}$ & $h$ & $N_{\text {leached }}$ & $E F_{N}$ & $N P P_{\text {leaves }}$ & $N P P_{\text {fine roots }}$ \\
\hline$+20 \%$ & $-0.10(-70)$ & $-0.53(54)$ & $-0.31(-12)$ & $-0.29(-18)$ & $-0.40(15)$ & $-0.68(97)$ \\
$-20 \%$ & $-0.64(86)$ & $-0.16(-54)$ & $-0.38(10)$ & $-0.41(18)$ & $-0.30(-15)$ & $-0.01(-97)$ \\
\hline
\end{tabular}

\subsection{General discussion}

This study demonstrated a clear connection between climate change mitigation potential and yield level of SRCW stand. A high yield means greater production of leaves, fine and coarse roots, which increases the annual carbon input to the soil. A low yield, on the other hand, can lead to a warming effect, by adding less $\mathrm{C}$ to the soil than is decomposed by soil microorganisms. To evaluate the possible significance of a longer coppice cycle related to a low SRCW productivity, the low yield scenario (no. 6) was also modelled with at 3-year coppice cycle. The outcome confirmed previous conclusions that the yield level is an important factor for obtaining a cooling effect on the temperature, and not the harvesting interval. 
Previous studies of SRCW and its effect on SOC have shown conflicting results, with some indicating a sequestering effect and others indicating the opposite [48]. One factor that may influence the results is the NPP distribution between aboveground and belowground biomass. Here, the relative distribution of NPP was assumed to be the same for all scenarios, independent of yield level, but if the NPP distribution varies due to changes in yield, it could affect the results, and would therefore be important to analyse further. The sensitivity analysis indicated that the NPP of fine roots affected the amount of SOC to a relatively large extent. However, the annual carbon input from fine root turnover $\left(i_{b}\right)$ for all scenarios in this study lay within the range for fine root productivity and mortality estimated by Rytter [49].

The inventory analysis showed that the energy ratio (ER) ranged from 20.4 to 27.1 for the seven scenarios. This agrees with the net energy ratio of 23 calculated by González-García et al. [14]. The mean annual energy input for the base scenario was $5.9 \mathrm{GJ} \mathrm{ha}^{-1} \mathrm{yr}^{-1}$ and the mean annual energy output was $150 \mathrm{GJ} \mathrm{ha}^{-1} \mathrm{yr}^{-1}$. This is in line with the LCA results reported by Börjesson [12], of $7.3 \mathrm{GJ} \mathrm{ha}^{-1} \mathrm{yr}^{-1}$ and $155 \mathrm{GJ} \mathrm{ha}^{-1} \mathrm{yr}^{-1}$ for energy input and output, respectively. A literature review by Djomo et al. [7] showed that LCAs of short rotation woody crops often use different system boundaries and impact indicators for evaluating the performance of bioenergy systems, which makes comparisons between studies problematic. Those authors concluded that the main causes of differing results between studies are the assumptions made regarding fertilisers, system boundaries, emissions of $\mathrm{N}_{2} \mathrm{O}$ and handling of GHGs. Of the studies reviewed that included SOC changes, the GWP ranged from -2.7 to $-4.7 \mathrm{~g} \mathrm{CO}_{2}$-eq $\mathrm{MJ}^{-1}$ biomass. For the base scenario in the present study the value was $-1.1 \mathrm{~g} \mathrm{CO}_{2}$-eq MJ ${ }^{-1} \mathrm{DH}$ produced, calculated for the whole time frame (years 0-100) (substitution effect not included).

Willow productivity depends on many factors, such as temperature, soil type and management. These factors are dependent on site-specific parameters that can vary from year-to-year. The sensitivity analysis showed that $r_{e}$ affected the sequestration potential to a great extent (Table 10). This indicates that using calibrated, site-specific data is of major importance. In this study $r_{e}$ was set to 1.0, which was calibrated for Ultuna soil data. According to Karlsson [37], average values for $r_{e}$ in Sweden in the period 1990-2004 ranged from 0.67 to 1.30, with the lowest values in the north and the highest in the south. The variations are primarily due to different climate conditions (e.g. temperature) in the regions. In the plain districts of Svealand, central Sweden, where the assumed site was located, $r_{e}$ was 1.04 [37], which agrees well with the value used in the present study. $r_{e}$ was assumed to be equal for green fallow, ley, annual crops and willow in this study, although crop type and management can affect $r_{e}$ [37].

Due to lack of site-specific data, a default value was used for calculating nitrogen leaching due to application of mineral fertiliser. Studies have shown that nitrogen leaching from willow is relatively low compared with that from other crops $[4,50]$, which indicates that the default value of $30 \%$ used here might be too high to represent willow cultivation. However, the sensitivity analysis showed that the final result was not sensitive to changes in the amount of nitrogen leaching, indicating that using the default value had a very small effect on the final results.

The scenario analysis showed that the increased quantity of soil organic carbon was only temporary and that once SRCW cultivation ended, the carbon could be re-emitted back to the atmosphere (Fig. 3). Nevertheless, the advantages of creating this temporary carbon sink should not be disregarded, since it contributes to positive values in short-term climate mitigation strategies. Demonstration of this temporal variation is one of the advantages of using the time-dependent LCA methodology developed by Ericsson et al. [3], as it would have been overlooked if only the metric GWP had been used.

All scenarios analysed in the present study showed a GHG reduction potential of 25 to $103 \%$ compared with the fossil reference systems (Table 9). Most scenarios showed a higher reduction potential than the range (90-99\%) stated in the review by Djomo et al. [7]. This larger GHG reduction potential may be the result of the present study including the SOC changes. Growing willow on marginal and low fertility land has been suggested as a good way to increase the amount of bioenergy produced without compromising food production. However, the resulting low SRCW yield may decrease the climate mitigation potential (Table 9, scenario 6). Better knowledge of how site-specific conditions affect yield is important for increasing the climate benefits of SRCW and also the economic benefits to farmers, which ultimately drives SRCW production. 


\section{Conclusions}

The climate impact of producing bioenergy from SRCW over a 100-year period ranged from -110 to $108 \mathrm{Mg}$ $\mathrm{CO}_{2}$-eq ha ${ }^{-1}$ when only including the willow system, or -3340 to $-854 \mathrm{Mg} \mathrm{CO}_{2}$-eq ha ${ }^{-1}$ when the effect of substituting fossil fuels was included. SRCW has the potential to act as temporary carbon sink, which can decrease the atmospheric concentration of GHGs and thereby mitigate climate change. The magnitude of this potential depends on growing conditions, with high willow yield giving the highest potential. However, very low yield can contribute to increasing global temperature, although the SRCW system still gives a much lower climate impact than DH produced from coal or natural gas. The previous land use scenarios resulted in a slightly higher initial SOC content but otherwise showed similar results to the base scenario. The climate effect of the carbon stored in soil and willow biomass is only temporary and once the plantation is terminated the carbon may be returned to the atmosphere again. This does not mean that carbon storage by SRCW is negligible, however, since reducing GHGs in the short term would help mitigate climate change.

\section{Acknowledgements}

This research was funded by the STandUP for Energy program and Swedish Research Council Formas (project number 2009-2056).

\section{References}

1. UNFCCC (2011) Report of the Conference of the Parties on its sixteenth session, held in Cancun from 29 November to 10 December 2010. Part Two: Action taken by the Conference of the Parties at its sixteenth session. Decisions adopted by the Conference of the Parties. FCCC/CP/2010/7/Add.1.

2. European Commission (2013) The EU climate and energy package. European Commission.

3. Ericsson N, Porsö C, Ahlgren S, Nordberg Å, Sundberg C, Hansson P-A (2013) Time-dependent climate impact of a bioenergy system - methodology development and application to Swedish conditions. GCB Bioenergy 5 (5):580-590. doi:10.1111/gcbb.12031

4. Heller MC, Keoleian GA, Volk TA (2003) Life cycle assessment of a willow bioenergy cropping system. Biomass and Bioenergy 25 (2):147-165. doi:10.1016/S0961-9534(02)00190-3

5. Statistics Sweden (2013) Land use in Sweden, sixth edition. Statistics Sweden, Regions and Environment Department, Örebro, Sweden

6. Hollsten R, Arkelöv O, Ingelman G (2013) Handbok för salixodlare (Manual for willow farmers). . Second edn. Jordbruksverket (Swedish Board of Agriculture), Jönköping, Sweden

7. Djomo SN, Kasmioui OE, Ceulemans R (2011) Energy and greenhouse gas balance of bioenergy production from poplar and willow: a review. GCB Bioenergy 3 (3):181-197. doi:10.1111/j.1757-1707.2010.01073.x

8. SOU (2007) Bioenergi från jordbruket - en växande resurs. Bilagedel (Bioenergy from agriculture - a growing resource. Appendix). Statens offentliga utredningar, Stockholm

9. Dimitriou I, Rosenqvist H, Berndes G (2011) Slow expansion and low yields of willow short rotation coppice in Sweden; implications for future strategies. Biomass and Bioenergy 35 (11):4613-4618. doi:10.1016/j.biombioe.2011.09.006

10. Quinkenstein A, Pape D, Freese D, Schneider BU, Hüttl RF (2012) Biomass, Carbon and Nitrogen Distribution in Living Woody Plant Parts of Robinia pseudoacacia L. Growing on Reclamation Sites in the Mining Region of Lower Lusatia (Northest Germany). International Journal of Forestry Research 2012:10. doi:10.1155/2012/891798

11. Cherubini F (2010) GHG balances of bioenergy systems - Overview of key steps in the production chain and methodological concerns. Renewable Energy 35 (7):1565-1573. doi:10.1016/j.renene.2009.11.035

12. Börjesson P (2006) Livscykelanalys av Salixproduktion (Life Cycle Assessment of Willow Production, english abstract) (Life Cycle Assessment of Willow Production). Institutionen för teknik och samhälle Avdelningen för miljö- och energisystem, Lund

13. González-García S, Mola-Yudego B, Murphy R (2013) Life cycle assessment of potential energy uses for short rotation willow biomass in Sweden. The International Journal of Life Cycle Assessment 18 (4):783-795. doi:10.1007/s11367-012-0536-2

14. González-García S, Mola-Yudego B, Dimitriou I, Aronsson P, Murphy R (2012) Environmental assessment of energy production based on long term commercial willow plantations in Sweden. Science of The Total Environment 421-422 (0):210-219. doi:http://dx.doi.org/10.1016/j.scitotenv.2012.01.041 
15. Fuglestvedt JS, Berntsen TK, Godal O, Sausen R, Shine KP, Skodvin T (2003) Metrics of Climate Change: Assessing Radiative Forcing and Emission Indices. Climatic Change 58 (3):267-331. doi:10.1023/A:1023905326842

16. Shine KP, Fuglestvedt JS, Hailemariam K, Stuber N (2005) Alternatives to the Global Warming Potential for Comparing Climate Impacts of Emissions of Greenhouse Gases. Climatic Change 68 (3):281-302. doi:10.1007/s10584-005-1146-9

17. Cherubini F, Guest G, Strømman AH (2012) Application of probability distributions to the modeling of biogenic CO2 fluxes in life cycle assessment. GCB Bioenergy 4 (6):784-798. doi:10.1111/j.17571707.2011.01156.x

18. Sathre R, Gustavsson L (2012) Time-dependent radiative forcing effects of forest fertilization and biomass substitution. Biogeochemistry 109 (1-3):203-218. doi:10.1007/s10533-011-9620-0

19. Zetterberg L, Chen D (2011) The time aspect of bioenergy - climate impacts of bioenergy due to differences in carbon uptake rates.

20. Baumann H, Tillman A-M (2004) The hitch hiker's guide to LCA: an orientation in life cycle assessment methodology and application. Studentlitteratur, Lund

21. Finnveden G, Hauschild MZ, Ekvall T, Guinée J, Heijungs R, Hellweg S, Koehler A, Pennington D, Suh S (2009) Recent developments in Life Cycle Assessment. Journal of Environmental Management 91 (1):1-21. doi:10.1016/j.jenvman.2009.06.018

22. Andrén O, Kätterer T, Karlsson T (2004) ICBM regional model for estimations of dynamics of agricultural soil carbon pools. Nutrient Cycling in Agroecosystems 70 (2):231-239. doi:10.1023/B:FRES.0000048471.59164.ff

23. Schlamadinger B, Apps M, Bohlin F, Gustavsson L, Jungmeier G, Marland G, Pingoud K, Savolainen I (1997) Towards a standard methodology for greenhouse gas balances of bioenergy systems in comparison with fossil energy systems. Biomass and Bioenergy 13 (6):359-375. doi:10.1016/S0961-9534(97)10032-0

24. Mola-Yudego B, Aronsson P (2008) Yield models for commercial willow biomass plantations in Sweden. Biomass and Bioenergy 32 (9):829-837. doi:10.1016/j.biombioe.2008.01.002

25. Guidi W, Pitre FE, Labrecque M (2013) Short-Rotation Coppice of Willow for the Production of Biomass in Eastern Canada. In: Matovic MD (ed). doi:10.5772/51111

26. Rytter R-M (2001) Biomass production and allocation, including fine-root turnover, and annual $\mathrm{N}$ uptake in lysimeter-grown basket willows. Forest Ecology and Management 140 (2-3):177-192. doi:10.1016/S03781127(00)00319-4

27. Brady NC, Weil RR (1999) The nature and properties of soils. Prentice Hall,

28. IPCC (2006) 2006 IPCC Guidelines for National Greenhouse Gas Inventories, Prepared by the National Greenhouse Gas Inventories Programme. IGES, Japan

29. Ahlgren S, Hansson P-A, Kimming M, Aronsson P, Lundkvist H (2009) Greenhouse gas emissions from cultivation of agricultural crops for biofuels and production of biogas from manure - Implementation of the Directive of the European Parliament and of the Council on the promotion of the use of energy from renewable sources. Revised according to instructions for interpretation of the Directive from the European Commission 30 July 2009. Uppsala

30. Aronsson P, Rosenqvist H (2011) Gödslingsrekommendationer för Salix 2011 (Recommendations for willow fertilisation 2011)

31. Aronsson P, Rosenqvist H, Dimitriou I (2014) Impact of Nitrogen Fertilization to Short-Rotation Willow Coppice Plantations Grown in Sweden on Yield and Economy. BioEnergy Research:1-9. doi:10.1007/s12155014-9435-7

32. Baky A, Forsberg M, Rosenqvist H, Jonsson N, Sundberg M (2009) Skördeteknik och logistik för bättre lönsamhet från små odlingar av Salix (Harvest and logistics for better profitability from small cultivations of Short Rotation Willow Coppice). Grödor från åker till energi. Institutet för jordbruks- och miljöteknik (JTI), Stockholm

33. Jonsson N, Jiris R (1997) Torrsubstansförluster och mikrobiell aktivitet vid lagring av salixflis (Dry matter losses and microbial activity during storage of willow chips). JTI,

34. Paulrud S, Fridell E, Stripple H, Gustafsson T (2010) Uppdatering av klimatrelaterade emissionsfaktorer (Updated climate related emission factors). . Swedish Meteorological and Hydrological Institute (SMHI). Norrköping, Sweden

35. Uppenberg S, Almemark M, Brandel M, Lindfors L-G, Marcus H-O, Stripple H, Wachtmeister A, Zetterberg L (2001) MILJÖFAKTABOK FÖR BRÄNSLEN Del 2. Bakgrundsinformation och Teknisk bilaga (ENVIRONMENTAL FACT BOOK FOR FUELS. Part 2. Background Information and Technical Appendix). Andra versionen (second edition) edn., Stockholm

36. Otabbong E, Persson J, Iakimenko O, Sadovnikova L (1997) The Ultuna long-term soil organic matter experiment. Plant and Soil 195 (1):17-23. doi:10.1023/A:1004276732679 
37. Karlsson T (2012) Carbon and Nitrogen Dynamics in Agricultural Soils. Model Applications at Different Scales in Time and Space. Doctoral Thesis, Swedish University of Agricultural Sciences, Uppsala

38. Aronsson H, Stenberg M, Rydberg T (2009) Kväve- och fosforutlakning från två växtföljder på lerjord med grön- och stubbträda (Nitrogen and phosphor leaching from two crop rotations on clay soil with green fallow and stubble, english abstract.). Ekohydrologi 113. Sveriges lantbruksuniversitet (SLU), Uppsala

39. Kätterer T, Andrén O, Persson J (2004) The impact of altered management on long-term agricultural soil carbon stocks - a Swedish case study. Nutrient Cycling in Agroecosystems 70 (2):179-188. doi:10.1023/B:FRES.0000048481.34439.71

40. Mulder K, Hagens NJ (2008) Energy Return on Investment: Toward a Consistent Framework. AMBIO: A Journal of the Human Environment 37 (2):74-79. doi:10.1579/0044-7447(2008)37[74:EROITA]2.0.CO;2

41. Ramaswamy V, Boucher O, Haigh J, Hauglustaine D, Haywood J, Myhre G, Nakajima T, Shi GY, Solomon S (2001) Radiative Forcing of Climate Change. In: Houghton JT, Ding Y, Griggs DJ et al. (eds) Climate Change 2001: The Scientific Basis. Contribution of Working Group I to the Third Assessment Report of the Intergovernmental Panel on Climate Change. Cambridge University Press, Cambridge, United Kingdom and New York, NY, USA, p 881

42. IPCC (2007) Contribution of Working Group I to the Fourth Assessment Report of the Intergovernmental Panel on Climate Change, 2007 Cambridge University Press, Cambridge, United Kingdom and New York, NY, USA

43. Joos F, Prentice IC, Sitch S, Meyer R, Hooss G, Plattner G-K, Gerber S, Hasselmann K (2001) Global warming feedbacks on terrestrial carbon uptake under the Intergovernmental Panel on Climate Change (IPCC) Emission Scenarios. Global Biogeochemical Cycles 15 (4):891-907. doi:10.1029/2000GB001375

44. IPCC (2001) Climate Change 2001: The Scientific Basis. Contribution of Working Group I to the Third Assessment Report of the Intergovernmental Panel on Climate Change. IPCC Third Assessment Report Climate Change 2001 Cambridge University Press, Cambridge, United Kingdom and New York, NY, USA

45. Huijbregts MAJ (1998) Application of uncertainty and variability in LCA. The International Journal of Life Cycle Assessment 3 (5):273-280. doi:10.1007/BF02979835

46. Röös E, Sundberg C, Hansson P-A (2010) Uncertainties in the carbon footprint of food products: a case study on table potatoes. The International Journal of Life Cycle Assessment 15 (5):478-488. doi:10.1007/s11367-010-0171-8

47. Björklund AE (2002) Survey of approaches to improve reliability in LCA. The International Journal of Life Cycle Assessment 7 (2):64-72. doi:10.1007/BF02978849

48. Dimitriou I, Mola-Yudego B, Aronsson P, Eriksson J (2012) Changes in Organic Carbon and Trace Elements in the Soil of Willow Short-Rotation Coppice Plantations. BioEnergy Research 5 (3):563-572. doi:10.1007/s12155-012-9215-1

49. Rytter R-M (1999) Fine-root Production and Turnover in a Willow Plantation Estimated by Different Calculation Methods. Scandinavian Journal of Forest Research (14: 6):526 — 537. doi:10.1080/02827589908540817

50. Dimitriou I, Mola-Yudego B, Aronsson P (2012) Impact of Willow Short Rotation Coppice on Water Quality. BioEnergy Research 5 (3):537-545. doi:10.1007/s12155-012-9211-5 